\title{
TRANSPORTATION COST MINIMIZATION OF A MANUFACTURING FIRM USING GENETIC ALGORITHM APPROACH
}

\author{
R.O. Edokpia 1,* and P.E. Amiolemhen ${ }^{2}$ \\ 1,2Department of Production Engineering, University of Benin, Benin City, Edo State, NigERIA. \\ E-mail addresses:1 1ralphedokpia@yahoo.com, ${ }^{2}$ patrick.amiolemhen@uniben.edu
}

\begin{abstract}
.
This study utilizes a Genetic Algorithm in solving the transportation problem of a beverage producing company in Nigeria with a view to minimizing the total transportation cost and obtaining an optimal schedule or schedules using transportation cost data from the peak periods (January to April and August to December) in the 2014/2015 production year which witnessed a fifty per cent (50\%) rise in the cost of diesel (a major contributor to the transportation cost) and a corresponding increase in its transportation cost as a result of government's removal of subsidy on petroleum products. The obtained data were analyzed and formulated into a transportation matrix with three routes and ten depots which were coded into strings after which the GA was applied to generate optimal schedules for six to nine depots that optimize the total transportation cost, revealing marked savings when compared with the company's current evaluation method. The cost savings reduced as the number of depots in the generated schedules increased with the six-depot schedule having the highest cost saving of $\$ 347,552$ daily.
\end{abstract}

Keywords: genetic algorithm, transportation problem, minimization, manufacturing firm, optimal schedules

\section{INTRODUCTION.}

The availability of products for purchase by consumers is critical to the survival of any manufacturing organization as even the best product in terms of quality, price and profitability needs to be readily available for the consumer at the point of demand and exchanged for a legal tender before the product can be said to have brought financial returns to the organization. Product distribution is therefore key to an organization's life.

Distribution occurs at a cost that does not add value in terms of size, quantity or quality to the product but ensures the sale of the product most times, for a profit. This cost is borne by either the producer or the consumer either way increasing the cost of production or the price of the commodity. This increase may not be favorable when the competitor sells for a lower price hence, it is necessary to incur the least possible distribution cost no matter the means of distribution as even a tiny improvement in the efficiency in the distribution process is transformed in a sensible monetary gain due to the fact that it is repeated every day of the year and gains are easily cumulated over time [1].
The transportation cost incurred varies with the mode of transportation chosen and the particular mode chosen depends on the characteristics of the mode and the company's need. In Nigeria, roads are the dominant mode of transportation as it accounts for about $90 \%$ of the internal movement of passenger and freight [2]. Manufacturers and service providers constantly make efforts to reduce this transportation cost either to increase their profit or to lower the price of their goods and services compared to that of their competitors.

The Transportation problem (TP) is probably the most important special linear programming problem in terms of the relative frequency with which it appears in the applications and also in the simplicity of the procedures developed for its solution [3]. It is one of the sub-classes of Linear Programming Problems in which the objective is to transport various amounts of a single homogeneous commodity that is initially stored at various origins to different destinations in such a way that the total transportation costs is minimum [4].

Aneja and Nair in [5] provided a simpler method for generating optimal solutions for bi-criteria TPs while

* Corresponding author, tel: +234-802-336-8811 
Barr et al. in [6] proposed a branch and bound algorithm for solving fixed charged transportation problems.

Vignaux and Michalewicz [7], used GA to solve the linear transportation problem adapting the relationship between the representation of structures and genetic operators for constrained problems. The Fixed-Charge Transportation Problem (FCTP) was solved in [8] using two Gas. Gen and Li [9] used a hybrid GA to solve the bi-criteria transportation problem using the concept of spanning trees.

Karaoglan [10] solved the problem of providing profit maximization in transporting the different characterized cargoes to determined ports by the ship fleets which contain different kinds of ships. Sen et al. [11] computed an optimal schedule for the transportation of rice from different suppliers in Silchar, India, to different destinations in Mizoram. He used various methods to obtain the initial basic feasible solution and finally computing an optimal solution using the MODI method which minimized the transportation cost and also the consumption of fuel in transporting the goods by the different carriers. Ramadan and Ramadan [12] proposed a hybrid twostage algorithm to find the optimal solution for the linear TP. The first uses a genetic algorithm and the second, starting from the result of the first, uses a revised simplex method to find an improved solution.

The successful application of GAs to combinatorial optimization problems have been documented in [13, 14].

The Federal Government's removal of subsidy on petroleum products in January 2011 resulted in an increase in the cost of doing business in Nigeria and one of the most affected areas was the cost of transportation which was a direct result of the increase in the pump price of petrol and even worse, the pump price of diesel $[15,16]$.

The minimization of the transportation cost of the company under study was previously done before the removal of the subsidy using a linear programming technique by Edokpia and Ohikhuare [17] .Vogel's Approximation Method was used to obtain initial basic feasible solution and both the modified distribution and the stepping stone methods were utilized to determine the optimal solution which revealed that, only six out of the eleven depots optimized cost and consequently received allocation. The company's costing policies have since been revised and although, there is an effort by the management of the company to minimize its transportation cost and also maintain its profitability, it involves methods that are not based on any model but by rule of thumb. Hence, the relevance of this work which incorporates a known model and takes into cognizance the present business climate in Nigeria and the company's operations policy in an attempt to optimize the transportation cost of the company. This present work, prompted by changes in the company's policies and operating costs, is an improvement on the previous work by utilizing the Genetic Algorithm (GA) approach which is more robust, to determine the optimal schedules for six, seven, eight and nine depots that optimized the transportation cost.

\section{METHODOLOGY.}

The material used for this study was the data obtained from the company for the peak period of January to April and August to December for the 2014/2015 production year and formulated into a balanced transportation matrix. The data are presented in Tables 1 to 4 . The optimization models used in this study are Linear Programming model (with Vogel's Approximation Method (VAM)) to determine the initial basic feasible solution because it gives a result which is closer to the optimal solution and Genetic Algorithm (GA) to determine the transportation schedule that will minimize the total transportation cost and satisfy the requirement at the depots.

\section{RESULTS.}

\subsection{Present Method of Transportation Costing by the Company. \\ 3.1.1 Cost of Diesel}

This is computed as:

Cost of diesel $=$ Volume in litres $\times$ Cost per litre (i.e. 157 per litre)

Diesel Quantity $=\frac{\text { Distance travelled to the depot }}{2.38}$

Table 1 shows the results obtained for the cost of diesel.

Table 1: Diesel cost and quantity.

\begin{tabular}{llll}
\hline $\begin{array}{c}\text { Location } \\
\text { (from plant } \\
\text { to) }\end{array}$ & $\begin{array}{c}\text { Distance } \\
(\mathrm{km})\end{array}$ & $\begin{array}{c}\text { Diesel Quantity } \\
\text { (litres) }\end{array}$ & $\begin{array}{c}\text { Diesel } \\
\text { Cost ( })\end{array}$ \\
\hline Beni $\mathrm{n}$ & 40 & 17 & 2,669 \\
Sapele & 155 & 65 & 10,205 \\
Warri & 209 & 88 & 13,816 \\
Ughelli & 261 & 112 & 17,584 \\
Ekpoma & 145 & 64 & 10,048 \\
Auchi & 242 & 102 & 16,014 \\
Lokoja & 506 & 218 & 34,226 \\
Agbor & 155 & 65 & 10,205 \\
Asaba & 245 & 110 & 17,270 \\
Onitsha & 267 & 117 & 18,369 \\
\hline
\end{tabular}




\subsubsection{Haulage Cost.}

Haulage cost is obtained using the following relations: Haulage cost $=$ Highest distance in a zone $\times$ Rate.

Table 2 shows the haulage cost from plant to the different locations.

Table 2: Haulage cost incurred by the company.

\begin{tabular}{lcccc}
\hline $\begin{array}{l}\text { Location ( from } \\
\text { Plant to) }\end{array}$ & $\begin{array}{c}\text { Distance } \\
(\mathrm{km})\end{array}$ & Zone $(\mathrm{km})$ & $\begin{array}{c}\text { Rate } \\
(\mathrm{A})\end{array}$ & $\begin{array}{c}\text { Haulage } \\
\text { Cost (A) }\end{array}$ \\
\hline- & - & $0-30$ & 622.9 & - \\
Benin & 40 & $31-50$ & 401.78 & 20,089 \\
Sapele & 155 & $151-200$ & 168.69 & 33,738 \\
Warri & 209 & $201-250$ & 151.15 & $37,787.5$ \\
Ughelli & 261 & $251-300$ & 136.91 & 41,073 \\
Ekpoma & 145 & $101-150$ & 186.30 & 27,945 \\
Auchi & 242 & $201-250$ & 151.15 & $37,787.5$ \\
Lokoja & 506 & $501-550$ & 114.09 & 62,750 \\
Agbor & 155 & $151-200$ & 168.69 & 33,738 \\
Asaba & 245 & $201-250$ & 151.15 & $37,787.5$ \\
Onitsha & 267 & $251-300$ & 136.91 & 41,073 \\
\hline
\end{tabular}

\subsubsection{Total transportation cost}

The beverage company calculates its transportation cost as follows:

Transportation cost per truck load $=$ Haulage cost + Cost of diesel

Total transportation cost $=$ Cost per truck load $\times$ Number of Trucks utilized

Number of trucks Quantity supplied

$=\frac{}{\text { average number of cases per pallet } \times \text { Number of pallets per truck }}$

\subsubsection{Demand and Supply}

The company operates a policy of supplying to every depot a quantity that is five percent (5\%) more than the daily demand. This ensures that no depot runs out of stock at any point in time. Also, if for any reason the supply from the plant is delayed, the excess products previously supplied will be used to temporarily satisfy the customers to avoid loss of customers' goodwill. The average daily demand, supply and the transportation costs incurred for the peak periods are given in Table 3.

\subsubsection{Daily Average Products Demand, Supply and Transportation Cost Per Truck}

The daily average quantity of products demanded, supplied and the transportation cost per truck load incurred through the three routes for the period under study is shown in Table 4.

\subsection{Model Development}

\subsubsection{The Model.}

Minimize (total cost) $\mathrm{Z}=c_{i j} X_{i j}$ (objective function) (1) Subject to

$x_{i j}=a_{i,} i=1,2, \ldots m$ (supply constraints)

$x_{i j}=b_{j}, j=1,2, \ldots n$ (demand constraints)

and

$x_{i j} \geq O$ for all $i$ and $j$.

Where

$i=$ Plant,$\quad j=$ depots, $c_{i j}=$ cost of transporting one truck load from plant to depot

$x_{i j}$ is the number of cases transported from plant to depot, $a$ is the amount of cases supplied by the plant through a route, $b$ is the amount of cases demanded by the depots on a route and $m$ is the number of rows and $n=$ number of columns.

\subsubsection{The Transportation Matrix.}

The transportation matrix implicitly expresses supply and demand constraints and the shipping or transportation cost between each demand and supply point. The acquired data are formulated into the transportation matrix shown in Table 5.

Table 3: Average daily demand, supply and transportation cost for the peak period.

\begin{tabular}{cccccccc}
\hline Depot & $\begin{array}{c}\text { Quantity } \\
\text { Demanded } \\
\text { (Cases per day) }\end{array}$ & $\begin{array}{c}\text { Quantity } \\
\text { Supplied } \\
\text { (Cases per } \\
\text { day) }\end{array}$ & $\begin{array}{c}\text { Excess } \\
\text { Supply } \\
\text { (Cases) }\end{array}$ & $\begin{array}{c}\text { Average } \\
\text { cases per } \\
\text { pallet }\end{array}$ & $\begin{array}{c}\text { Cost per } \\
\text { truck (\#) }\end{array}$ & $\begin{array}{c}\text { Number of } \\
\text { trucks per } \\
\text { day }\end{array}$ & $\begin{array}{c}\text { Transportation } \\
\text { cost per day (\#) }\end{array}$ \\
\hline Benin & 8,000 & 8,400 & 400 & 55 & 22,758 & 7 & 159,309 \\
Warri & 14,000 & 14,700 & 700 & 55 & $51,603.5$ & 12 & 619,242 \\
Ughelli & 5,000 & 5,250 & 250 & 55 & 58,657 & 4 & 24,628 \\
Sapele & 3,000 & 3,150 & 150 & 55 & 43,943 & 3 & 131,829 \\
Ekpoma & 1,500 & 1,575 & 75 & 55 & 37,993 & 2 & 75,986 \\
Auchi & 4,000 & 4,200 & 200 & 55 & $53,801.5$ & 4 & 215,206 \\
Lokoja & 1,700 & 1,785 & 85 & 55 & 96,977 & 2 & 193,954 \\
Agbor & 1,500 & 1,575 & 75 & 55 & 43,943 & 2 & 87,886 \\
Asaba & 4,000 & 4,200 & 200 & 55 & $54,992.5$ & 4,5 & 219,970 \\
Onitsha & 15,000 & 15,750 & 750 & 55 & 59,442 & 12 & 713,304 \\
\hline Total & 57,700 & 60,585 & 2,885 & & & & $2,651,314$ \\
\hline
\end{tabular}


Table 4: Supply routes, costs and quantities for the peak period

\begin{tabular}{ccccc}
\hline Route & Depot & Cost per truck (\#) & Demand (cases) & Supply (cases) \\
\hline \multirow{3}{*}{ North } & Ekpoma & 37,993 & 1,500 & 1,575 \\
& Auchi & $53,801.5$ & 4,000 & 4,200 \\
& Lokoja & 96,977 & 1,700 & 1,785 \\
\hline Total & & & 7,200 & 7,560 \\
\multirow{3}{*}{ East } & Agbor & 43,943 & 1,500 & 1,575 \\
& Asaba & $54,992.5$ & 4,000 & 4,200 \\
& Onitsha & 59,442 & 15,000 & 15,750 \\
\hline Total & & & 20,500 & 21,525 \\
\hline \multirow{3}{*}{ South } & Benin & 22,758 & 8,000 & 8,400 \\
& Sapele & 43,943 & 3,000 & 3,150 \\
& Warri & $51,603.5$ & 14,000 & 14,700 \\
& Ughelli & 58,657 & 5,000 & 5,250 \\
\hline Total & & & 30,000 & 31,500 \\
\hline
\end{tabular}

Table 5: Transportation matrix formulated from the acquired data

\begin{tabular}{ccccccc}
\hline & 1 & 2 & 3 & 4 & DUMMY & SUPPLY \\
\hline North & Ekpoma \#37,993 & Auchi \# 53,801.5 & Lokoja \# 96,977 & & 0 & 7,560 \\
East & Agbor \# 43,943 & Asaba \# 54,992.5 & Onitsha \# 59,442 & & 0 & 21,525 \\
South & Benin \# 22,758 & Sapele \# 43,943 & Warri \# 51,603.5 & Ughelli \# 58,657 & 0 & 31,500 \\
\hline Demand & 11,000 & 11,000 & 30,700 & 5,000 & 2,885 & 60,585 \\
\hline
\end{tabular}

Table 6: Modified transportation matrix formulated from the acquired data

\begin{tabular}{cccccc}
\hline & 1 & 2 & 3 & 4 & SUPPLY \\
\hline North & Ekpoma \$37,993 & Auchi \# 53,801.5 & Lokoja \$ 96,977 & & 7,560 \\
East & Agbor \$ 43,943 & Asaba \# 54,992.5 & Onitsha \# 59,442 & & 21,525 \\
South & Benin \# 22,758 & Sapele \# 43,943 & Warri \# 51,603.5 & Ughelli \# 58,657 & 31,500 \\
\hline Demand & 11,550 & 11,550 & 32,235 & 5,250 & 60,585 \\
\hline
\end{tabular}

From Table 5, the supply is more than the demand by 2,885 cases hence, the need for the dummy column to create a balanced matrix. The dummy represents three depots with zero cost implications having the excess supply allocated to it. It is possible that in the initial or optimal solution, one or more of the dummy depots receives allocation which is at no incurred cost. This means that the company supplies at no cost incurred which is a false representation of the data. To avoid this, the excess supply to a depot is incorporated into the demand from that depot and this way, a balanced matrix is created. The three routes and the respective depots on each route are indicated in Table 6.

In Table 6, all the excess supplies have been incorporated into the demands from each depot. Consequently, the demand is now equal to supply and no dummy depot is required.

The initial basic feasible solution is computed using Vogel's Approximation Method while the optimal solution is computed using the modified distribution method. Using the model (i.e. eq.(1)), the objective function and constraints for Table 6 are represented as follows:

Minimize:

$$
\begin{aligned}
& 37993 X_{11}+43943 X_{21}+22758 X_{31}+53801.5 X_{12} \\
&+ 54992.5 X_{22}+43943 X_{32} \\
&+96977 X_{13}+59442 X_{23} \\
&+51603.5 X_{33}+58657 X_{34}
\end{aligned}
$$

Subject to:

Supply constraints:

$$
\begin{array}{cl}
\mathrm{x}_{11}+\mathrm{x}_{12}+\mathrm{x}_{13} & \leq 7,560 \\
\mathrm{x}_{21}+\mathrm{x}_{22}+\mathrm{x}_{23} & \leq 21,52 \\
\mathrm{x}_{31}+\mathrm{x}_{32}+\mathrm{x}_{33} & \leq 31,500
\end{array}
$$

Demand constraints:

$$
\begin{array}{cc}
\mathrm{x}_{11}+\mathrm{x}_{21}+\mathrm{x}_{31} & \leq 11,550 \\
\mathrm{x}_{21}+\mathrm{x}_{22}+\mathrm{x}_{23} & \leq 11,550 \\
\mathrm{x}_{13}+\mathrm{x}_{23}+\mathrm{x}_{33} & \leq 32,235
\end{array}
$$

Non-negativity constraints

$$
x_{34} \geq 5,250 \text {; for all } x_{11} \text { to } x_{34} \geq 0
$$

A necessary condition for the existence of a feasible solution to the transportation problem stated above as contained in [3] is:

$$
a_{i}=b_{j}
$$


Under the condition that total supply from the factory $=$ total demand at the depots.

\subsubsection{Solution by Genetic Algorithm.}

The solution to the transportation problem in this study using Genetic Algorithm utilizes the following concept:

(1) A depot represents a gene in a string

(2) . A string consist ten depots: Ten strings are set as the initial population and the ten strings are formed such that every depot occupies a different position in each string so as to have equal chances in the process of replication.

(3) For the purpose of identification, the depots are numbered 1 to 10 in a string in increasing order of transportation cost of a truck load from the plant to the depots. The depots and their numbers are given below:

1 - Benin; 2 - Ekpoma ; 3 - Sapele; 4 - Agbor;

5 - Warri; 6 - Auchi; 7 - Asaba; 8 - Ughelli;

9 - Onitsha and 10 - Lokoja

(4) The fitness function of a string is the calculated total transportation cost of the allocation to the depots contained in the string. The string with the lowest transportation cost is regarded as one with the best fitness function and is chosen for further iteration.

(5) The transportation cost is calculated using only the quantity supplied as the company incurs cost only on goods supplied and all allocation due to a route must be exhausted by the depots along the route.

(6) The initial strings or parents are randomly selected in twos for crossover and mutation.

(7) Crossover at randomly chosen points, is first performed on all ten initial strings (Parents) using two parents at a time to produce two offspring after which mutation is done to the offspring with the best fitness function. The crossover point is indicated by a line drawn across the parents.

(8) The fitness function (Transportation cost) is computed after every crossover and mutation. This process is repeated until no better solution can be achieved.

(9) After an operation (crossover or mutation), only strings that yielded schedules having transportation costs lower than the current cost of the company can be involved in further iteration.

(10) All strings suitable for replication or further iteration must contain depots 1(Benin), 5
(Warri) and 9 (Onitsha) as the company regards the three as major depots.

(11) Termination is done when there is no further improvement in the fitness function or transportation cost of the strings. This could occur when the fitness function of a parent is better than the fitness function of all the offspring or when only one string produces a better solution.

(12) An offspring is identified by the prime symbol (') and the number of the parent that produced it. The prime symbol indicates the generation of the offspring.

For example, ' = first generation, " = second generation and so on.

(13). The number of times a depot occurs in a string after an operation denotes its strength and the allocation it gets.

(14) If a depot occurs once or more than once, it gets the allocation supplied to it as stated in table 3.7 and stands a chance of possessing the allocation due to a depot along similar route that did not occur in the string.

(15) If depots along similar route occur equal number of times in a string, they get their allocation and share equally, the allocation due to the depot on the same route that did not occur in the string.

(16) If a depot does not occur in a string, it does not get any allocation.

(17) For this study, only optimal schedules of six, seven, eight and nine depots will be generated.

(18) All strings that generated similar number of depots will be grouped after which those that produced transportation cost lower than the company's current cost and whose schedule contains depots 1, 5 and 9 will be selected for further iteration.

(a) The Initial Population: The company operates ten depots hence the initial population consists of all ten depots in ten strings such that a depot occupies a different position in each string as shown in Table 7. Allocation to all ten depots means that the company incurs a daily transportation cost of $\$ 2,651,314$. The process of minimizing the transportation cost is to identify using GA technique, the depots among the ten presently operated (optimal number of depots) that should receive allocation and at a cost lower than the current cost incurred by the company. The depots that minimize the transportation cost are the depots that after crossover and mutation, occur in the new string and their fitness function (transportation cost) is 
lower than the current transportation cost of the company. This is repeated until an optimal solution is achieved.

\section{Table 7: Initial population (representation of the ten depots)}

\begin{tabular}{c|l|l|l|l|l|l|l|l|l|l|}
\hline $\begin{array}{c}\text { String } \\
\text { /Parent } \\
\text { Number }\end{array}$ \\
\hline 1 & 1 & 2 & 3 & 4 & 5 & 6 & 7 & 8 & 9 & 10 \\
\hline 2 & 9 & 5 & 6 & 3 & 8 & 7 & 2 & 10 & 1 & 4 \\
\hline 3 & 8 & 4 & 2 & 5 & 7 & 10 & 3 & 1 & 6 & 9 \\
\hline 4 & 2 & 6 & 4 & 10 & 3 & 9 & 1 & 7 & 5 & 8 \\
\hline 5 & 10 & 9 & 8 & 7 & 6 & 5 & 4 & 3 & 2 & 1 \\
\hline 6 & 4 & 3 & 10 & 6 & 1 & 8 & 5 & 9 & 7 & 2 \\
\hline 7 & 3 & 1 & 7 & 9 & 2 & 4 & 8 & 6 & 10 & 5 \\
\hline 8 & 7 & 10 & 1 & 8 & 4 & 2 & 9 & 5 & 3 & 6 \\
\hline 9 & 6 & 7 & 5 & 2 & 9 & 1 & 10 & 4 & 8 & 3 \\
\hline 10 & 5 & 8 & 9 & 1 & 10 & 3 & 6 & 2 & 4 & 7 \\
\hline
\end{tabular}

(b) Crossover: Crossover Operation for two randomly selected strings from the Initial Population is performed until all the strings have been involved in a crossover. The result yielded various offspring with different schedules and transportation costs.

(c) Viable offspring: The viable offspring are all strings that resulting from crossover, produced a transportation cost (fitness function) that is lower than the company's present cost and whose schedule includes depots 1 (Benin), 5 (Warri) and 9 (Onitsha). They are indicated below and selected for further iteration.

(d) Mutation: Mutation between two randomly selected offspring was done producing different results. Some mutations produced strings with reduced number of depots while others resulted in more depots. All viable offspring from the crossover operation become parents for mutation and termination occurs when only one string generates a better solution than is already existing or when no better solution was generated.

\section{(e) The Optimal Schedules.}

The results by Genetic Algorithm (GA) were limited to the optimal schedules for six, seven, eight and nine depots considering only the supply as the company incurs cost only when a supply is facilitated. The depots are numbered 1 to 10 in order of increasing transportation cost from the plant. The optimal schedules and the transportation costs incurred are given in tables below:

Figure 2: Transportation schedule and costs after crossover operation

$\underline{\text { Six depots. }}$

\begin{tabular}{|c|c|c|c|c|c|c|c|c|c|c|c|}
\hline String Number & \multicolumn{10}{|c|}{ String } & \multirow{2}{*}{$\begin{array}{c}\text { Transportation cost }(\mathrm{N}) \\
2,374,707\end{array}$} \\
\hline $10^{\prime}$ & 5 & & 9 & 1 & 1 & 8 & 5 & 9 & 7 & 2 & \\
\hline $4^{\prime}$ & 2 & 7 & 5 & 2 & 9 & 9 & 1 & 7 & 5 & 8 & $2,396,499$ \\
\hline \multicolumn{12}{|l|}{ Seven depots. } \\
\hline String Number & \multicolumn{10}{|c|}{ String } & Transportation Cost ( \\
\hline $7^{\prime}$ & 3 & 1 & 7 & 9 & 2 & 2 & 9 & 5 & 3 & 6 & $2,467,492$ \\
\hline $9^{\prime}$ & 6 & 7 & 5 & 2 & 9 & 1 & 1 & 7 & 5 & 8 & $2,366,996$ \\
\hline $2^{\prime}$ & 9 & 5 & 6 & 3 & 8 & 7 & 3 & 1 & 6 & 9 & $2,519,972$ \\
\hline
\end{tabular}

Eight depots.

\begin{tabular}{c|c|c|c|c|c|c|c|c|c|c|c}
\hline \multicolumn{10}{c}{ String Number } \\
\hline $7^{\prime}$ & 3 & 1 & 7 & 9 & 2 & 4 & 9 & 5 & 3 & 6 & Transportation Cost (N) \\
\hline $9^{\prime}$ & 6 & 7 & 5 & 2 & 9 & 1 & 0 & 7 & 5 & 8 & $2,398,501$ \\
$2^{\prime}$ & 9 & 5 & 6 & 3 & 8 & 7 & 2 & 1 & 6 & 9 & $2,589,795.5$ \\
\cline { 2 - 5 } & & 10 & $2,542,156.5$ \\
\hline
\end{tabular}

Nine depots.

\begin{tabular}{|c|c|c|c|c|c|c|c|c|c|c|c|c|}
\hline String Number & \multicolumn{11}{|c|}{ String } & Transportation Cost ( $\#$ ) \\
\hline $1^{\prime}$ & 1 & 2 & 3 & 4 & 5 & 6 & 7 & 8 & 9 & 1 & & $2,457,357$ \\
\hline $7^{\prime}$ & 3 & 1 & 7 & 9 & 2 & 4 & 8 & 5 & 3 & 6 & & $2,457,357$ \\
\hline $8^{\prime}$ & 7 & 10 & & 1 & 8 & 4 & \begin{tabular}{|l|l|}
2 & 9 \\
\end{tabular} & 5 & 3 & 5 & & $2,570,928$ \\
\hline $6^{\prime}$ & 4 & & 3 & 0 & 6 & $\begin{array}{ll}5 & 1\end{array}$ & 8 & 5 & 9 & 4 & 7 & $2,575,325$ \\
\hline $9^{\prime}$ & 6 & 7 & 5 & 2 & 9 & 1 & 10 & 4 & 5 & 8 & & $2,572,689$ \\
\hline
\end{tabular}


Table 9: Optimal schedule for six depots by Genetic Algorithm

\begin{tabular}{|c|c|c|c|c|c|}
\hline $\begin{array}{c}\text { To } \rightarrow \\
\text { From } \downarrow\end{array}$ & & & & & SUPPLY \\
\hline NORTH & $\begin{array}{c}\text { 2) Ekpoma } \\
7560\end{array}$ & $\begin{array}{c}6) \\
\text { Auchi }\end{array}$ & $\begin{array}{c}10) \\
\text { Lokoja }\end{array}$ & & 7,560 \\
\hline EAST & 4) Agbor & $\begin{array}{c}7) \\
\text { Asaba } \\
5775\end{array}$ & $\begin{array}{c}9) \\
\text { Onitsha } \\
15750\end{array}$ & & 21,525 \\
\hline SOUTH & $\begin{array}{c}\text { 1) Benin } \\
9975\end{array}$ & $\begin{array}{c}3) \\
\text { Sapele }\end{array}$ & $\begin{array}{c}\text { 5) Warri } \\
16275\end{array}$ & $\begin{array}{c}8) \\
\text { Ughelli } \\
5250\end{array}$ & 31,500 \\
\hline
\end{tabular}

Transportation Cost $=\$ 2,303,762$.

Table 10: Optimal schedule for seven depots by Genetic Algor

\begin{tabular}{|c|c|c|c|c|c|}
\hline $\begin{array}{c}\text { To } \rightarrow \\
\text { From } \downarrow\end{array}$ & & 2) & & & SUPPLY \\
\hline NORTH & $\begin{array}{c}\text { Ekpoma } \\
1575\end{array}$ & $\begin{array}{c}\text { 6) Auchi } \\
5985\end{array}$ & $\begin{array}{c}10) \\
\text { Lokoja }\end{array}$ & & 7,560 \\
\hline EAST & 4) Agbor & $\begin{array}{c}7) \\
\text { Asaba } \\
4987.5\end{array}$ & $\begin{array}{c}9 \text { ) } \\
\text { Onitsha } \\
16537.5\end{array}$ & & 21,525 \\
\hline SOUTH & $\begin{array}{c}\text { 1) Benin } \\
\text { 13650 }\end{array}$ & $\begin{array}{c}\text { Sapele } \\
3150\end{array}$ & $\begin{array}{c}\text { 5) Warri } \\
14700\end{array}$ & $\begin{array}{c}\text { 8) } \\
\text { Ughelli }\end{array}$ & 31,500 \\
\hline
\end{tabular}

Transportation Cost $=\$ 2,339,118$.

Table 11: Optimal schedule for eight depots by Genetic Algorithm

\begin{tabular}{|c|c|c|c|c|c|}
\hline $\begin{array}{c}\text { To } \rightarrow \\
\text { From } \downarrow\end{array}$ & & & & & SUPPLY \\
\hline NORTH & $\begin{array}{c}\text { 2) } \\
\text { Ekpoma } \\
2467.5\end{array}$ & $\begin{array}{c}\text { 6) Auchi } \\
5092.5\end{array}$ & $\begin{array}{c}10) \\
\text { Lokoja }\end{array}$ & & 7,560 \\
\hline EAST & $\begin{array}{c}4 \text { ) Agbor } \\
1575\end{array}$ & $\begin{array}{c}7 \text { ) } \\
\text { Asaba } \\
4200\end{array}$ & $\begin{array}{c}9 \text { ) } \\
\text { Onitsha } \\
15750\end{array}$ & & 21,525 \\
\hline SOUTH & $\begin{array}{c}\text { 1) Benin } \\
10150\end{array}$ & $\begin{array}{c}3 \text { ) } \\
\text { Sapele } \\
4900\end{array}$ & $\begin{array}{c}5 \text { ) Warri } \\
16450\end{array}$ & $\begin{array}{c}\text { 8) } \\
\text { Ughelli }\end{array}$ & 31,500 \\
\hline
\end{tabular}

Transportation Cost $=$ 2,341,573.

Table 12: Optimal schedule for nine depots by Genetic Algorithm

\begin{tabular}{|c|c|c|c|c|c|}
\hline $\begin{array}{c}\text { To } \rightarrow \\
\text { From } \downarrow\end{array}$ & & & & & SUPPLY \\
\hline NORTH & $\begin{array}{c}\text { 2) } \\
\text { Ekpoma } \\
2467.5\end{array}$ & $\begin{array}{c}\text { 6) Auchi } \\
5092.5\end{array}$ & $\begin{array}{c}10) \\
\text { Lokoja }\end{array}$ & & 7,560 \\
\hline EAST & $\begin{array}{c}\text { 4) Agbor } \\
1575\end{array}$ & $\begin{array}{c}7) \\
\text { Asaba } \\
4200\end{array}$ & $\begin{array}{c}9 \text { ) } \\
\text { Onitsha } \\
15750\end{array}$ & & 21,525 \\
\hline SOUTH & $\begin{array}{c}\text { 1) Benin } \\
8400\end{array}$ & $\begin{array}{c}\text { 3) } \\
\text { Sapele } \\
3150\end{array}$ & $\begin{array}{c}5 \text { ) Warri } \\
14700\end{array}$ & $\begin{array}{c}\text { 8) } \\
\text { Uhelli } \\
5250\end{array}$ & 31,500 \\
\hline
\end{tabular}

Transportation Cost $=\$ 2,457,357$.

\section{DISCUSSION.}

The current daily transportation cost incurred by the company on supply to all ten depots through three routes is $\# 2,651,314$. Four optimal transportation schedules using Genetic Algorithm approach were determined. The four schedules revealed supply to six, seven, eight and nine depots, all at a minimized transportation cost when compared with the current cost incurred by the company. In all four schedules, the company's three major depots namely Benin, Warri and Onitsha were included as required by the company.

A Six- depot optimal schedule (Table7) computed using Genetic Algorithm (GA) resulted in a daily transportation cost of $\$ 2,303,762$ giving a cost saving of $\$ 347,552$ per day compared to the current daily transportation cost the company incurs.

The optimal schedule for seven depots by GA (Table 8) resulted in a daily transportation cost of $\$ 2,339,118.5$ and a cost saving of 312,195.5 per day when compared with the company's current daily transportation cost.

The eight-depot optimal schedule (Table 9) by GA reveals that the company will incur a daily transportation cost of $\mathrm{N} 2,341,573.5$ with daily cost savings of $\mathrm{N} 309,704.5$ while the optimal schedule by GA for allocation to nine depots (Table 10) ensures the company incurs a transportation cost of \$2, 457,357 per day thereby generating cost savings of $\$ 193,957$ daily compared to its current cost. Termination for the GA iterations occurred when no further improvement was achieved in the minimization of the transportation cost for the generated schedules. Given that the factory capacity can always satisfy a $5 \%$ increase in the daily demand from the depots and the number of depots, their capacities, the transportation routes and costs are constant, any of the above optimal schedules is applicable to the entire peak period.

The GA result, reveals only the depots that optimize the transportation cost of the company with the possibility of four different schedules having from six to nine depots with the most savings on the six-depot schedule. This means that the company can decide which schedule best suits its business objectives and constraints and make profit as all four schedules result in cost savings while satisfying the customers.

\section{CONCLUSION.}

The desire for better sales, larger market and wider reach by business organizations are pointers to the 
fact that transportation and distribution costs will continue to be incurred if goods and services are moved from the point of manufacture to the point of demand. Though transportation cost cannot be absolutely eliminated, a reduction is possible by the use of transportation models and heuristic methods to determine the schedule and cost that minimizes the cost of transportation while satisfying the demand of the consumers.

Having made a comparison of the current policy and transportation costs of the company under study with the results obtained from the application of Genetic Algorithm (GA), a marked savings was achieved.

The Current daily total transportation cost of the company for the period under study is $\$ 2,651,314$. The total cost achieved by the application of GA are 2,303,762 for six(6) depots, $\$ 2,339,118.5$ for seven (7) depots, $\mathrm{N} 2,341,573.5$ for eight (8) depots and $\mathrm{N}$ $2,457,357$ for nine(9)depots. Cost savings from the GA were achieved indicating that the application of a model optimizes the transportation cost and also indicates the depots to be satisfied and their requisite allocation.

Information gathered from the company reveal that the company does not base their policy on any model hence the relevance of this work. Also, from the optimal solutions achieved, not all the depots optimize cost consequently, some depots do not receive any allocation but since they are already in existence, it is recommended that smaller chains of distribution could be created from the serviced depots along similar routes thereby ensuring that the consumers' goodwill is not lost to competition.

\section{REFERENCES}

[1] Rizzoli, A. E., Olivierio, F., Montemanni, R. and Gambardella, L. M. Ant Colony Optimization for Vehicle Routing Problems :From Theory to Application. Swarm Intelligence, Vol. 1, no. 2, pp. 135-15. (2007).

[2] Oni, S. I. Public-Private Partnership Relations in Urban Transportations in Nigeria. Technical Paper, Department of Geography, University of Lagos, Lagos, Nigeria. http://www.codatu.org. (2004).

[3] Sharma, J. K. Extensions and special cases of the transportation problem: A survey. Digital Library of India, Vol. 9, no. 9, pp. 928- 940. 1997.

[4] Alam, T. and Rastogi, R. Transportation Problem: Extensions and Methods- An Overview. VSRDInternational Journal of Business and Management Research, Vol. 1, no. 2, pp. 121-126. (2011).
[5] Aneja, Y. P. and Nair, K.P.K. The Bi-Criteria Transportation Problem. Management Science, Vol. 25, no. 1, pp. 73-78. (1979).

[6] Barr, R. S., Glover, F. and Klingman, D. A new optimization method for large scale fixed charge transportation problems. Operations Research, Vol. 29, no. 3, pp. 448-463. (1981).

[7] Vignaux, G. A. and Michalewicz, Z. A. Genetic Algorithm for Linear Transportation Problem. IEEE Transactions on Systems, Man and Cybernetics, Vol. 21, no. 2, pp. 445-452. (1991).

[8] Gottlieb, J. and Paulmann, L. Genetic Algorithms for Fixed Charge Transportation Problem. World Congress on Computational Intelligence, IEEE Press, pp. 330-335, (1998).

[9] Gen, M. and Li, Y. Spanning Tree-based Genetic Algorithm for Biciteria Transportation Problem. Computers and Industrial Engineering, Vol. 35, pp. 531-534. (1998).

[10] Karaoglan, A. D. Tanker Scheduling by using Optimization Techniques and a case study. $B A U$ FBE, Vol. 9, no. 2, pp. 48-62. ( 2007).

[11] Sen, N., Som, T. and Sinha, B.. A study of transportation problem for an essential item of southern part of north eastern region of India as an OR Model and use of object oriented programming. International Journal of Computer Science and Network Security, Vol. 40, no. 4, pp. 78-86 . (2010).

[12] Ramadan, S. Z. and Ramadan, I. Z. Hybrid Two-Stage Algorithm for Solving the Transportation Problem, Canadian Centre of Science Education, Vol. 6, no. 4, pp. 12-22. (2012).

[13] Chambers, L. (ed.) Practical Handbook of Genetic Algorithms: New Frontier, Volume II.CRC Press, Boca Raton, Florida. (1995).

[14] Reeves, C. R. Genetic algorithms for the Operations Researcher. INFORMS Journal on Computing, Vol.9, pp. 231-250. (1997).

[15] Deshmukh, N. D. An innovative method for solving the transportation problem. International Journal of Physics and Mathematical Sciences, Vol. 2, no. 3, pp. 86-91. 2012.

[16] Edokpia, R. O. and Ohikhuare, K. O. Transportation Cost Minimization of a Manufacturing Firm using Linear Programming Technique. Advanced Materials Research, vol.367, no. 685, pp. 685-695, (2011).

[17] Holland, J.H. Adaptation in Natural and Artificial Systems. University of Michigan press, Ann Arbor, Michigan. (1975).

[18] Goldberg, D. E. Genetic Algorithms in search Optimization and Machine Learning. AddisonWesley, Longman Publishing Company Inc. Boston, MA, USA. (1989). 